\title{
One Belt One Road Initiative: A Study through Economic Diplomacy Perspective
}

$\sim$ Niha Pandey ${ }^{1}$

\begin{abstract}
With the third wave of globalization and information revolution, the demand for cross border relations has augmented. In international system, international relations have evolved significantly, which has created a demand to enhance relations among states. The relations among states are driven by Diplomacy. In addition, Diplomacy has always been a means or a tool to conduct international relations in order to achieve its national interest. With this note, this paper presents a study on One Belt One Road Initiative (OBOR) in relation to China's Economic Diplomacy. The paper accommodates the major theoretical approaches of International Relations including Liberalism and Realism perspectives to precisely analyze China-led OBOR. The paper concludes by assessing the probabilities for future connectivity between South Asia and China.
\end{abstract}

Keywords: Economic Diplomacy, One Belt One Road Initiative (OBOR), South Asia, International Relations, China's Foreign Policy

\section{Introduction}

In 21st century, the international relations and diplomacy dimensions has pivoted from the Euro-centric focus to a more eastern or specifically, the Asian region. The emerging powers in Asian region are challenging the world order mainly in the economic terms and thus, the role of diplomacy itself has become very crucial in all respects. As stated by Chester Bowles, a former American diplomat, "We are coming to realize that foreign operations in today's world call for a total diplomacy" (Hamilton \& Langhorne, 2011, p. 185) The diplomatic practices follows one major facets in the current era i.e. adapting a Total Diplomacy framework to conduct state to state relations. Essentially, diplomacy is the art of negotiations and representation between states. It is one of the vital instruments to conduct foreign policy of states. According to Annette Baker Fox (1959), "Diplomacy is the tool of statecraft" (p.40) Diplomacy plays a very crucial role in the contemporary international relations. As illustrated by Hans Morgenthau (1985), he describes the quality of diplomacy as one of the significant elements of national power. He further argues, "The conduct of nation's foreign affairs by its diplomats is

1 Pandey is a faculty member at Master's in International Relations and Diplomacy (MIRD) program, Faculty of Humanities and Social Sciences, Tribhuvan University, Kritipur 
for national power in peace what military strategy and tactics by its military leaders are for national power in war. It is the art of bringing the different elements of national power to bear with maximum effect upon those points in international situation which concern the national interest more directly" (Morgenthau 1985, p.159). The quality of diplomacy is one of the central characteristic while conducting state to state relations when the contemporary international system is primarily guided by the Neo-liberal institutionalist perspective. The relationship among states are intertwined where the diplomatic conducted between states because very vital. With this note, the emerging economic power conduct their state relation on the foundation of economic diplomacy. Economic Diplomacy is one of the many facets of Diplomacy. It is a form of Diplomacy which employs complete range of economic means to achieve states national interest. Economic Diplomacy encompasses range of economic activities which is not only confined to imports and exports but also assistance, negotiation, aid, lending and trade agreements. It also deals with economic policy issues which ensure stability in economic policies in international arena. Generally diplomacy (including economic diplomacy) is 'the means by which states pursue their foreign policies' (Berridge 2002,p.3). Therefore, economic diplomacy is one of the major instruments to promote national interest of a state.

Economic Diplomacy is the fundamental feature of China's Foreign Policy. China's remarkable economic rise applies carrot approach to accumulate soft power. In the contemporary context, China's One belt One Road (OBOR) Initiative is reflected as an aspect of Economic Diplomacy. Simultaneously, it can be portrayed as one of the feature of regional economic diplomacy. One Belt One Road Initiative is a regional cooperation which seeks to promote connectivity via land and maritime silk routes. It is a development strategy and framework, proposed by China's President Xi Jinping focusing on connectivity and cooperation among states. Utilizing the domestic strategy of western development to correct the economic imbalance, China views Belt and Road as a grand strategy to link China by first connecting it with the world (Nicolas, 2015, p. 49). The "One Belt" and "One Road" is focused on 'Silk Road Economic Belt' and 'Maritime Silk Road' respectively. This initiative comprises of two main apparatus. First, the land-based economic belt and second, the ocean-based economic belt. The Silk Road Economic Belt focuses on connecting China to Europe via South Asia, South East Asia, Central Asia and Russia. The Maritime Silk Road focuses on utilizing the sea ports to connect China with Europe and Africa. The prime focus is based on promoting connectivity across Asia, Africa and Europe. The one belt one road initiative encompasses of countries situated on original Silk Road. Traditionally, it was a bottom-up trade activity driven by states outside China, however OBOR is designed as a top-down activity which has been proposed by China's ruling leaders. 
According to OBOR document, this project is planned along the principles and codes of the United Nations Charter. It supports the Five Principles of Peaceful Coexistence also known as the Panchasheel that was circulated during Non-Aligned Movement in the early days of cold war period. Based on these principles, the document articulates comprehensible course of action that outlines the future policies of the initiative. The cooperation priorities encompasses of five vital areas: Policy Coordination, Facilitating Connectivity via Infrastructure Construction, Unrestricted and Free Trade across borders, Financial Integration and escalating people-to-people ties. In these five areas, Facilitating Connectivity via Infrastructure Construction has been the dominant element of this initiative. Therefore, OBOR initiation reflects the economic diplomatic approach where the focus resides on expanding the infrastructure development and economic prosperity from regional level to the systemic level.

\section{International Relations and One Belt One Road: Theoretical Approaches}

In Post World War scenario, the entire dynamics of international system has changed significantly. As argued by few scholars, there has been a paradigm shift in the understanding of the international relations perspective. This was the point of time when the first great debate of International relations became prominent where the Realist and Liberalist school of thought interpreted the world events. This changes in international system has led to change in the discipline of International Relations. As illustrated, there have been many contrasting and conflicting views advocated by different schools of thought within International Relations. With this note, the failure of League of nation in the 1930's gave rise to a new view of world order based on Realist perspective but post-Cold war or during the ending days of cold war, the revival of liberalism perspective, which is known as Neo-liberal institutionalist perspective changed the dynamics of international system. Joseph S Nye and Robert Keohane revolutionized the concept wherein the Liberal school of thought took a new path in understanding the international relations among states. Thus, these new paradigm could be used to further understanding the OBOR initiative.

\section{Liberalism standpoint}

Comprehending Liberalism, it can be referred to as the growing interdependence of states through economic exchange, global institutions and societal norms. According to Andrew Moravcsik (1997), the central idea behind liberalism is "the relationship between states and the surrounding domestic and transnational society, in which they are embedded, critically shapes state behavior by influencing the social purposes underlying state preferences." (p.516). Liberalism argues that the norms and institutions that direct the global community shape a state's international strategy. With this note, liberalist idea illustrates that the interdependence unites China to the significance of its community, particularly the South Asian community. China's Economic diplomacy 
in South Asia is creating profound associations among Beijing and its neighbors and accordingly this affiliation has advanced into inter-dependent South Asian community that upholds integrated ambitions.

Since the announcement of One Belt One Road initiative, China has managed the development of a vigorous infrastructure plans in South Asia. China has opted to generate a win-win setting all the way through the Indian Ocean region. According to Liberal school of thought, the initiative generates prospects for common development supporting multilateral growth and address failures that present global and regional establishments are unable to surmount. In 2011, the People's Republic of China Information Office of the State Council issued Peaceful Development White paper that assessed China's purpose on peaceful development throughout the state's "advance toward modernization." After Chinese economic and infrastructure revival in South Asia and two years prior to the proclamation of One Belt One Road Initiative, the document signifies China's publicly affirmed strategic goals to construct a multilateral system that encourages economic harmony, cooperation, common development and a win-win setting. Therefore, this document evidently describes on the foundation of Liberalist perspective.

Similarly, the Belt and Road initiative can be examined as a result of both Chinese customs along with the progression of as a scheme that began with China's opening in 1978 which is reaffirmed under the present Chinese leadership. Whilst screening in the concert of South Asia, China's attempt for non-violent dogma demonstrates a harmony in liberal motivation and in consequence the initiative evident' China's endorsement of peaceful development generating an all-inclusive, win-win setting backing up developing states.

Illustrating an example, Chinese Bank funding in significant ports in Sri Lanka and Bangladesh in order to open bottlenecks, depicts a model of a liberalist idea (Ynuling, 2015). Similarly, the announcement made by President Xi emphasizes on diplomatic work with neighboring countries is out of need to achieve the great rejuvenation of Chinese nation which will eventually lead to building an environment of "common prosperity" and connectivity between China and South Asia (Chen, 2013). Likewise, the proposal of community of 'Common Destination' has also been offered. This mutual prosperity is displayed in the form of economic assistance, trade relations and the most vital aspect, infrastructure development. Since 2003, Chinese exports to its South Asian neighbors have doubled. Countries such as Bangladesh, Nepal and Sri Lanka has an increased bilateral investment which has grown to almost $\$ 500$ million. This escalation occurred prior to the announcement of OBOR initiative which solely relied on the bilateral relation between China and the respective countries. Hence, there is a reason to believe that the increased connectivity via OBOR projects will result in 
greater economic growth. As a whole, China has set a trail for economic success as a number of infrastructure projects are announced and are in progress under the initiation.

Additionally, infrastructure development in South Asian region not only reflects economic gains but also illustrated potential for Regional Stability. Pakistan can be demonstrated as a very good example. The China- Pakistan Economic Corridor can be viewed as a doorway to South Asia. The $\$ 46$ billion invested by China to complete the modernization projects on Gwadar port indicates a turning point for a vulnerable and a lawless region into a lively center of economic growth (Overholt, 2015). Basically, it implies that china is adhering to a model alike United States approach throughout the cold war- Economic Growth produces Stability- where the cooperation between states can help prosper the entire region.

\section{Realism standpoint}

In the other hand, this OBOR initiative can also be discoursed on the basis of Realism school of thought. Assuming that the international system operates in anarchic system, Realist school argues that the international system is stimulated with "enduring propensity for conflict between states" (Walt, 1998, p.30). This statement can be examined that a state's interest can be amplified through resource paucity, geopolitical approach and economic ambitions. According to Jason J. Blazevic (2009), "The importance of such aspects is magnified by geography and access to resources, which further complicates international relations. Undeniably, nations are competitive players pursuing their significant national interests, i.e. national security and survival.” (p.60). The tendency to increase its sphere of influence in different part of the world can also be argued under the OBOR initiation as it can be demonstrated that China itself is vying for a 'Peaceful Rise' eventually aiming to be a superpower in the international system.

Since, the introduction of OBOR in 2015, realist school of thought argues that the economic corridors designed in South Asia is to expand the Sino-centric schema which is also contended as a Grand Strategy. First, the infrastructure development will advance China's national interest throughout the South Asian region and second, the infrastructure connection will augment the status of China both economically and politically to its neighbors by generating dependency on China's diplomatic policy.

According to Friedberg on the discussion over U.S - China Strategy (2015):

"China's growing interest in South Asia is a reaction to state's increasing need for natural resources. Since 2000, China's interest in South Asia has centered on securing access in, out and through this geo-strategic body of water. Similarly, in 2003, the "Malacca Dilemma" states that "whoever controls the strait of Malacca will also have a stranglehold on the energy route of China." 
This argument put forward by Friedberg illustrates the geopolitical significance within the entire Asian region and the availability of resources along with the paucity of it, being one of the crucial factor for instituting this initiation. National resources are one of the significant element of national power and thus, with increased availability of natural resources the state itself can be in a greater position. Further on, in reference to this argument, consequences of Karokorum Highway in Pakistan and maritime facilities in Sri Lanka demonstrate such indication. Regardless of speculations that this mission will fabricate a win-win setting, the OBOR projects are being negatively affected. In Pakistan's case, reports have claimed that the Gilgit-Baltistan area has been futile to improve the economy and uplift the residents living conditions.

As a whole, OBOR project is offering prospects to generate powerful economic and political footsteps throughout South Asia. Liberal scholars argue that the enlargement of Chinese participation in South Asia is an example of China self-regulating influence yet realist scholars believe that despite of the proposed idea that China places on its events, the recently developed infrastructure and corridors flowing directly from Beijing is based on the preponderance of power. Therefore, there is an immense fear to India that china's influence in South Asia will impinge on its own sphere of influence as India itself is also vying to be hegemonic power in the south Asian region.

Furthermore, the idea of OBOR Initiative is perceived as an evolving geopolitical facet in the early 21 st century. It reflects an example of modern economic diplomacy which entitles for integration of the region into various areas. The growth of Asia today has led to revolutionary set of conditions in global geopolitics and geo-strategy.

The geopolitical and geo-strategic attribute of this plan offers an extraordinarily remarkable background. According to Geopolitical feature, it circles around two theoretical concepts: the 'Heartland' and 'Rimland' of international supremacy. The article advanced by Halford Mackinder in 1905 "Geographic Pivot of History", theorized the idea of Heartland which articulates that the states that presides over East Europe (currently Eurasia) controls the Heartland and "rules the world". , In defense, Nicholas John Spykman, critiqued this idea by portraying an example of Russia. Russia being an agrarian power in the 20th century occupied the Heartland but did not have the capacity to control the globe. On this ground, he introduced a new idea of "Rimland" perspective, which elaborates that the stripe of coastal land that encircles Eurasia was more significant than the Heartland and its domination allowed control of Asian continent which was strategically for important. These geopolitical lenses can be applied in South Asian Continent wherein it can be examined that the OBOR projects can be a medium to command the various geopolitical and geo-strategic locations. In 21 st century the concept of OBOR is yet to be tested in and thus, both the heartland and Rimland theory are integrated in the two primary division of OBOR. The Silk Road 
Initiative and the 21st century Maritime Road can be explained on the basis of both the arguments put forward under the heartland and Rimland perspective. Nonetheless, in the current scenario, it is a major challenge for one single state to rule the entire landmass .Therefore, in this context geopolitical setting, it can be one of the major factors to understand OBOR.

\section{Opportunities and Challenges}

In the contemporary International Relations, China posits a strong position where it illustrates itself as a rising power. This has completely changed the dynamics of world order in the international system. Since the end of Cold War, the international structure has shifted from a unipolar international system to a Multi-polar international system. The international structure can be seen to reside on two dimensions. Firstly in political paradigm, United States of America is still politically powerful but in economic paradigm, China is growing its economy tremendously which can be demonstrated as one of the powerful states in economic context. With this note, China's OBOR projects could be one of the factors that may facilitate it to be a powerful state in the international system. This augmentation in economic sector will eventually help to enhance the economy of its peripheral states where in China shares its border with five South Asian Countries. Therefore, OBOR can be a vital project for South Asian countries to promote its connectivity and also become a bridge to South East Asian States.

Elaborating on the opportunities advanced by this initiation, China is one of the leaders in context to high-speed rail technology and other infrastructure engineering. China has created a miracle in the development sector and thus, OBOR project can be one of the initiatives to reflect this efficiency and promote connectivity via railways and infrastructure development in South Asian countries. The economic corridors can be one of the examples in this background. The infrastructure projects prior to Belt and Road Initiative known as China-Pakistan Economic Corridor (CPEC) and BangladeshChina-India-Myanmar (BCIM) Economic cooperation had provided an enthusiastic and binding institutions to amalgamate key players. Similarly, in infrastructure perspective, OBOR is seeking to develop infrastructure linking Kunming to Kolkata and Mandalaya to Myanmar.

Second, China comprises of huge capital and a surplus capacity for infrastructure building. Consequently, the surplus capacity building can be a chief aspect for development of South Asian countries because states in this region lag behind in development sectors and infrastructural development. Similarly, in futuristic perspective, physical development will eventually change the social thinking connecting ChinaIndia-Nepal with modern transport infrastructure. Thus, this will eventually minimize the geopolitical skepticism between China and India. Opportunities for South Asian 
countries are infinite but in India's context, OBOR initiative will push both the states to work closely without generating skepticism in geopolitical and geo-strategic context.

Third, South Asian Association for Regional Cooperation (SAARC) is an organization that has collaborated the South Asian states. The organization comprises of eight sovereign states wherein China neighbors with five of them. China is an observer state in SAARC and has close bilateral relations with all the individual states. In this context, OBOR has created a huge opportunity for trade and investment in this region and can boost the regional integration further. Therefore, this will assist to persuade more fragmentation of production and services within the states promoting connectivity further.

Fourth, OBOR project is a cross border phenomena that caters to regional integration on economic perspective. As mentioned in the OBOR document, one of the priorities of the project is to facilitate connectivity. Hence, the success of OBOR project will lead to reducing the trade costs and will fill the regional infrastructure gaps. With increase in the trade flows will lead to creating employment and eventually lead to reducing poverty. Therefore, regional economic interaction will gain higher growth in South Asian countries.

Lastly, connectivity via sub regional cooperation will end the isolation of landlocked countries like Nepal and Bhutan because the OBOR initiative will provide global access to such landlocked countries. Therefore, these are the few opportunities that can be analyzed on the basis of OBOR project.

On the other side, in south Asian region, there is a power struggle among China and India. Given the border war in 1962, there is a point of contention bounded by the region. The trade relations between China and South Asia have been rising enormously. Concurrently, the trade between China and India has also augmented which has left New Delhi to fear that China's OBOR project will re-shape India's sphere of influence (Pant, 2014).India has made a reservation over the Belt and Road initiative in the implementation process concentrating on the security implications. India has asserted that China's naval presence in Indian Ocean Region has produced security concerns which can be reflected through the associations of US- India in security dimensions. As a result, US- India seems to be adapting an encirclement maneuvers in order to create a deadlock in the OBOR projects and also stall the advancement of BCIM. Therefore, this can be illustrated as one of the major challenges for the operation of OBOR Initiative.

Further challenges can be expounded in the geographical structure of this region. The projects of OBOR initiative will incur higher cost because of the landscape and landmass. This may create hindrance in the efficiency of the projects. Similarly, the quality of institutions in the South Asian region can also be a major challenge for installing OBOR 
project and promoting connecting. For example, the political instability in Nepal is one of the major hindrance to bring forward the railway connection from Shigatse to Kerung to Pokhara and lastly Lumbini. With this note, for OBOR project to become successful, it is essential for states in domestic level to create a stable environment.

According to the report prepared by University of Wisconsin for the US Government Office of South Asian Policy, "OBOR creates opportunities for growth and development as a wider variety of exports flow from China into the region, and as Chinese outward direct investment improves infrastructure and creates job." Per se, future evidence of win-win environment must illustrate continued increased trade between China and South Asian states and sustained South Asian GDP growth that is comparable to China's growth.

With challenges in hand, the first step to make this initiative successful is finding a common ground. In south Asia, the OBOR project can succeed if China can advance a stable relation with major stakeholders in the South Asian region. As an emerging power, it faces competition and even attempts of containment by existing powers, China has reached a stage where it needs to adopt a total diplomatic approach focused under economic strategy. China should have a multi-layered cooperation with the principal stakeholders, which can help to endure the global pressure to a greater degree. Therefore, in South Asia, India signals this point, deeming China as a strategic challenge to New Delhi's affairs and maintain balance between the historic animosity among India and Pakistan.

\section{Conclusion}

In conclusion, One Belt One Road Initiative(OBOR) is anticipated to result into achieving economic and infrastructural opportunities by various countries, chiefly by South Asian Countries, which would eventually lead to multitudes of benefits. On the other hand, these opportunities may lead to unanticipated challenges and misunderstanding to the stakeholders. Thus, China should also ensure on implementing the right policies and governance in order to make this initiative successful. All in all, this initiative can be considered as one of the evolutionary project, which shall eventually have a greater impact on the global economic affairs and probably to introduce a New International Economic Order through OBOR projects.

\section{References}

Bayne, N., \& Woolcock, S (2007) The New Economic Diplomacy: Decision Making and Negotiation in International Economic Relations 2nd edition. Aldershot: Ashgate.

Berridge, G.R. \& James, A. (2003) A Dictionary of Diplomacy 2nd edition. Houndmills: Palgrave. 
Blazevic, J., "Defensive Realism in the Indian Ocean: Oil, Sea Lanes and the Security Dilemma,"China Security 5, no.3 (2009): 59-71

Brunjes, E., "China's Increased Trade and Investment in South Asia (Spoiler Alert: It's the Economy)," (master's thesis, University of Wisconsin, 2013), ix.

Chen, X., "Creating a Favorable New Landscape for Diplomacy," China-US Focus, November 13, 2013, http://www.chinausfocus.com/foreign-policy/creating-afavorable-new-landscape-for-diplomacy/.

Fox, A. B. (1959). The Power of Small State: Diplomacy in World War II. Chicago, Illinois: The University of Chicago Press.

Hamilton, K., \& Langhorne, R. (2011). The Practice of Diplomacy: Its Evolution, Theory and Administration (2nd ed.). Third Avenue, New York: Routledge

Morgenthau, H., \& Thompson, K. (1985). Politics Among Nations: The struggle for Power and Peace (6th edition). New York: McGraw-Hill

Moravcsik, A., "Taking Preferences Seriously: A Liberal theory of International Politics" International Organizations 51, no.4 (1997): 516

Nicolas, D. P. (2015). Chinese Infrastructure in South Asia: A Realist and Liberalist Perspective(master's thesis). NAVALPOSTGRADUATE SCHOOL MONTEREY, CALIFORNIA.

Overholt, W., “One Belt, One Road, One Pivot.” Global Asia 10, no. 3 (2015). https:// www.globalasia.org/article/confront-or-accommodate-the-maritime-silkroadwill-test-us-china-rivalries/.

Pant, H., "India and China slugging It Out in South Asia," Japan Times, December 21,2014,http://www.japantimes.co.jp/opinion/2014/12/21/commentary/worldcommentary/india-china-slugging-south-asia/.

People's Republic of China, Information Office of the State Council. (2011). Beijing: Information Office of the State Council. Retrieved January 02, 2016, from http:// www.gov.cn/english/official/2011-09/06/content_1941354.htm

Spykman,N. J. (1938), Geography and Foreign Policy I, in American Political Science Review, Feb 1938, pp.28-50 in which he articulates the idea of geopolitics

"Survival interview: Aaron L. Friedberg on the debate over U.S. China strategy," The International Institute of Strategic Studies: The Survival Editor's Blog, May29, 2015, http://www.iiss.org/en/politics\%20and\%20strategy/blogsections/2015932e/may-7114/debate-over-us- china-china-strategy-f18a.

Walt, S. M. (1998). International Relations: One World, Many Theories. Foreign Policy,110, 29-32.

Ynuling, Z., "One Belt, One Road: A Chinese Overview.” Global Asia 10, no. 3 (2015). https://www.globalasia.org/issue/chinas-new-silk-roads/.

9006 